\title{
Manufacture of fiber composite materials musa acuminate $I$. prepared by the randomized position with polymer matrix resin
}

\author{
Lailan Ni'mah ${ }^{1, *}$, M. Rizka Akbari ${ }^{2}$, Ferdi Akhmad Khan $^{3}$, and M. Afief Ma'ruf ${ }^{4}$ \\ 1,2,3 Lambung Mangkurat University, Chemical Engineering, Faculty of Engineering, Jl. A. Yani KM 36 Banjarbaru, South Kalimantan, \\ Indonesia \\ ${ }^{4}$ Lambung Mangkurat University, Civil Engineering, Faculty of Engineering, Jl. A. Yani KM 36 Banjarbaru, South Kalimantan
}

\begin{abstract}
Composite is a system composed by mixing two or more different materials, in the form and composition of materials that do not dissolve each other. In general, the composite material is a material that has some properties that may not be owned by each component. This study aims to determine the effect of immersion banana fiber in $\mathrm{NaOH}$ solution, the composition ratio of the difference between the banana fiber to resin used and find the resistance of composite products produced against the pressure test and tensile test. This study begins with taking fiber banana followed by delignification process to remove lignin in the raw material, then molding composites made with a composition that has been set. The resulting composite will be tested durability to perform pressure tests (ASTM D 695) and a tensile test (ASTM D 638). To test tap on the position of the randomized to the concentration of $\mathrm{NaOH} 0 \%, 3 \%, 5 \%$ and $7 \%$ respectively, each for $53.716 \mathrm{~N} / \mathrm{mm} \mathrm{2,} 43.184 \mathrm{~N} / \mathrm{mm} \mathrm{2,81.724} \mathrm{N/mm} 2$ and $30.032 \mathrm{~N} / \mathrm{mm} 2$. For tensile test on an randomized position with $\mathrm{NaOH}$ concentration of $0 \%, 3 \%, 5 \%$ and $7 \%$ respectively, each for 21.519 M.Pa, 18.359 M.Pa, 31.033 M.Pa and 21.064 M.Pa.
\end{abstract}

\section{Introduction}

Bananas as the leading commodity, contributing to the national fruit production reached 34\% (angka tetap Tahun 2004, Ditjen. Horti, 2005) is 4,874,439 tonnes of $14,348,456$ tons of national fruit production. Distribution of banana production areas in almost all regions in Indonesia, with distribution of the highest production was in Java (West Java, East Java and Central Java) in the amount of $3,108,377$ tons or $63.7 \%$ of the total national production of bananas, whereas in other areas such as Sumatra (Lampung, North Sumatra and South Sumatra) amounted to 940390 tonnes, or $19.3 \%$, Sulawesi (South Sulawesi, Central Sulawesi and North Sulawesi) by 6\%, the rest of the Nusa Tenggara, Bali and Kalimantan. Based on the Census of Agriculture 2003 (SP 2003, BPS 2004), households of farmers involved in the cultivation of bananas in Indonesia as many as 16 million or 30.3\% of farm households as a whole, amounting to 52.9 million farm households. This illustrates that every 10 farmers, three of whom grow bananas well as garden plants as well as plant garden / farm. Banana production in the province of South Kalimantan, according to fixed numbers in 2004, the directorate general of horticulture in 2005, and the directorate general of fruit crops in 2006 reached 67362 tons of harvested area of $1,873 \mathrm{Ha}$.

Banana tree is a tree is familiar to the people of Indonesia. Banana production is still focused on the fruit as a commodity in trade. Until now, the stem of a banana tree mostly used by farmers in small amounts, especially as tobacco wrapping materials and materials straps on food wrappers. The potential for a large banana tree frond has not been used for materials in engineering, particularly the field of engineering, especially in the field of composites. If this technology can be developed that will enhance the use value of banana waste, so the waste banana not just be a waste of plantations but can be harnessed into something more economical.

Manufacture of composite materials have previously had to go through a treatment for the process of making the fiber because if the banana is used without treatment will cause the fiber surfaces become dirty and formed wax that can cause the fiber surface becomes softer, so that the bonding fibers to the matrix becoming weaker and lower tensile strength ${ }^{[1]}$.

\subsection{Composite}

Composite is a system composed by mixing two or more different materials, in the form and composition of materials that do not dissolve each other. In general, the composite material is a material that has some properties that may not be owned by each component. In this sense it is certainly the combination is not limited to material matriknya ${ }^{[2]}$.

The nature and characteristics of the composite ${ }^{[3]}$ are determined by:

1. The constituent composite material. Characteristics of the composite. Determined based on the characteristics of the constituent material, according to

* Corresponding author: lailan.nimah@gmail.com 
the rule of mixture so that the results will be inversely proportional.

2. Form and preparation of structural composites. Form and way of preparation of composites will affect the characteristics of the composite.

3. Interaction between constituent. When there is interaction between authors will improve the properties of the composites.

Composite materials are generally composed of two elements, namely fiber (fiber) as a filler, and binder fiber is called the matrix. Inside the main element is a composite fiber, while the bonding material using a polymer material that is easily formed and has a high binding power. The main use of its own fiber to determine characteristics of composite materials, such as stiffness, strength and mechanical properties of the other. As fillers, fibers used to resist most of the forces acting on the composite material, the matrix itself has the function of protecting and binding fibers in order to work well against the forces that occur. Therefore, the material used for the fiber material is strong, rigid and brittle, while the matrix material chosen materials are soft and resistant to chemical treatment.

Natural fibers have a strength ranging from $220 \mathrm{MPa}$ (palm fruit fiber) to $1500 \mathrm{MPa}$ (flax fiber) and a Young's modulus between $6 \mathrm{GPa}$ (palm fruit fiber) up to $80 \mathrm{GPa}$ (flax), as well as its density ranges from $1.25 \mathrm{~g} / \mathrm{cm}^{3} \mathrm{up}$ to $1.5 \mathrm{~g} / \mathrm{cm}^{3}$. While the glass fiber type $\mathrm{E}$ has a strength $2200 \mathrm{MPa}$ and a Young's modulus of $73 \mathrm{GPa}$, and a density of $2.55 \mathrm{~g} / \mathrm{cm}^{3}$, so for some natural fibers such as flax, hemp, jute and sisal have specific modulus competitive with glass fiber ${ }^{[4]}$. In the merger between the fiber and resin, fiber will serve as an amplifier (reinforcemenfiller) which typically have high strength and stiffness, while functioning as an adhesive or a resin matrix to maintain the position of the fiber, transmits shear forces and also functions as a coating fibers. Predominantly fiber will determine the strength and stiffness of the composite. The smaller the size of the fiber, it will provide adhesion and strength is getting better, because the ratio between the surface and the larger the fiber volume ${ }^{[5]}$. The mechanical properties of the composite is strongly influenced by the orientation of the fibers, the composite can be quasi-isotropic when used short fibers that are oriented randomly, anisotropic when used long fibers are oriented in multiple directions, or orthotropic when used long fibers that are oriented primarily in the direction perpendicular ${ }^{[6]}$.

The need for the placement of fiber and different fiber direction in Figure 1 to make fiber reinforced composites differentiated into several sections including ${ }^{[7]}$ :

a. Continuous fiber composite (fiber-reinforced composites to continue)

Continuous or uni-directional, fiber arrangement has long and straight, forming lamina between matriknya. Composite type is most commonly used. This type has a weakness on the separation between the layers. This is because the strength between layers is affected by the matrix.

b. Woven fiber composite (composite reinforced with fibers woven).
The composite is not easily influenced by the separation between the layers because of the composition of the fiber also binds between the layers. But the arrangement of fibers that are not so straight prolongation result will weaken the strength and stiffness. Composite consists of matrix layer followed by a layer of woven fiber arrangement.

c. Discontinuous fiber composite

Composites with shorter fibers, random type often used in the production of large volumes due to lower manufacturing costs. Disadvantages of this type of random fibers is still below the mechanical properties of the fiber reinforcement with a straight on the same type of fiber.

d. Hybrid fiber composite

Composite is a combination of the type of straight fibers with random fibers. This type is used in order to change their shortcomings properties of both types and can combine strengths.

\subsection{Fiber Of Musa Acuminate L.}

South Kalimantan is one banana production centers mainly bananas Kepok. This variety is a type of processed bananas which have advantages in flavor and relatively more resistant to impact, and storability. Kepok banana production areas are in Hulu Sungai Tengah, Banjar, Tapin and Kotabaru. Production Distribution of banana varieties in the central areas of major banana in South Kalimantan.

Banana fiber obtained from kepok banana tree (Musa paradisiaca) is a fiber that has good mechanical properties. The mechanical properties of banana fiber has a density of $1.35 \mathrm{~g} / \mathrm{cm} 3$, the content of $63-64 \%$ cellulose, hemicellulose $(20 \%)$, lignin content of $5 \%$, the average tensile strength of $600 \mathrm{MPa}$, the average tensile modulus $17.85 \mathrm{GPa}$ and the length of $3,36 \%{ }^{[8]}$.

\subsection{Polymer Resin}

Unsaturated polyester resin or polyester is often called the matrix of the composite. These resins include also the thermoset resin, the liquid resin thermoset polymer is converted into hard and brittle solids that formed by chemical crosslinking polymer chains that form very strong. Thermoset resins do not melt due to heating. At the time of printing, the resin is not necessary given the pressure, because when the liquid still has a relatively low viscosity, hardens at room temperature with the use of a catalyst without generating gas (unlike other thermoset resins). In general, polyester resin strong against acid except oxidizing acids, but has a low resistance to bases. If the resin is put into boiling water for 300 hours it will be broken and cracked. Polyester is widely used in the form of composite materials ${ }^{[9]}$. 


\section{Material And Methodology}

\subsection{The course of study}

Raw material such as banana bark is cleaned and dried for 1 week, then dikerus with a wire brush and drawn fiber. After the obtained fiber, the fiber is soaked in a solution of $\mathrm{NaOH}$ with each concentration of $3 \%, 5 \%$ and $7 \%$ for 2 hours. Then the fiber is washed with distilled water and drained.

\subsection{Manufacture of composites}

Banana fibers are arranged in a mold, then doused with a resin matrix in accordance with a predefined composition.

\subsection{Analysis}

Analysis of the results of the composite is done with 2 test sample, namely the pressure test (ASTM D 695) and a tensile test (ASTM D 638).

\section{Results and Discussion}

\subsection{Compressive Strength Testing}

Testing the compressive strength of the composite obtained from the maximum suppressive force divided by the cross-sectional area is pressed, with volume $99 \%$ polyester, catalyst $1 \%$ and $2,500 \mathrm{~mm}$ wide field press ${ }^{2}$. Data from the measurement of compressive strength of the composite polyester are shown in Table 1.

Table 1. Results of testing the compressive strength of the composite polyester.

\begin{tabular}{|c|c|c|c|c|}
\hline$\underset{(\%)}{\mathrm{NaOH}}$ & $\begin{array}{l}\text { Number } \\
\text { of Fibers }\end{array}$ & Fc $(N)$ & $\operatorname{Ac}\left(\mathrm{mm}^{2}\right)$ & $\begin{array}{c}\text { Compressive } \\
\text { Strength } \\
\left(\mathrm{N} / \mathbf{m m}^{2}\right) \\
\end{array}$ \\
\hline 0 & 30 & 134.290 & 2.500 & 53,716 \\
\hline 3 & 30 & 107.960 & 2.500 & 43,184 \\
\hline 5 & 30 & 204.310 & 2.500 & 81,724 \\
\hline 7 & 30 & 75.080 & 2.500 & 30,032 \\
\hline
\end{tabular}

Variation randomized position obtained graph the relationship between the compressive strength and $\mathrm{NaOH}$ involves the variation shown in Figure 1.

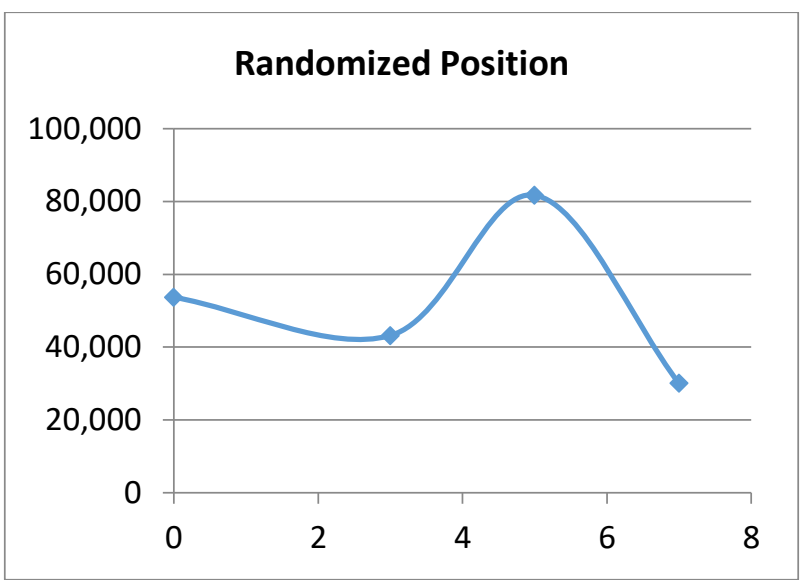

Fig. 1. Graph compressive strength of the composite polyester with treatment variations $\mathrm{NaOH}$.

Based on Figure 1 compressive strength values obtained for randomized sequentially position each of $53.716 \mathrm{~N} / \mathrm{mm}^{2}, 43.184 \mathrm{~N} / \mathrm{mm}^{2}, 81.724 \mathrm{~N} / \mathrm{mm}^{2}$ and $30.032 \mathrm{~N} / \mathrm{mm}^{2}$.Seen that the compressive strength of greatest value to a position held by the variation randomized treatment of $\mathrm{NaOH} 5 \%$ of $81.724 \mathrm{~N}$ / $\mathrm{mm}^{2}$. The compressive strength of the composite material is strongly influenced by the composition of the constituent materials, the bond between peguat and filler composite. One of the physical properties of composite boards are very influential on other mechanical properties are therefore increasingly meeting the density of a filler so it's better compressive strength value ${ }^{[10]}$.

The compressive strength of the composite material in this study was obtained from 8 specimens with a variation of the position of the fiber that is randomized and $\mathrm{NaOH}$ treatment variations respectively $0 \%, 3 \%, 5 \%$ and $7 \%$ cuboid measuring $5 \times 5 \times 5 \mathrm{~cm}$. Based. The compressive strength of the composite material in the randomized position with variation of $\mathrm{NaOH} 3 \%$ and $7 \%$ decline in value. For a variation of $3 \% \mathrm{NaOH}$ was influenced by the decrease in the incidence of voids in the composite, voids or air bubbles affect the bond between the matrix and fiber. The gap in the fiber or fibers less than perfect shape that causes the matrix will not be able to fill the empty space in the mold. If the composite is receiving load, the voltage area will move to the void that will reduce the strength of the composite. Composite strength is inversely proportional to the void that is more voids, the composite will be more fragile and void if its less then the composite will be stronger. As for the variation of $\mathrm{NaOH}$ $7 \%$ decline is not only influenced by the emergence of $a$ void, but also due to the variation of $7 \% \mathrm{NaOH}$ treatment causes the fiber diameter will be enlarged so that the composite strength will be reduced. Composite strength is inversely proportional to the diameter of the fiber used, the smaller the diameter of the fibers will produce a higher strength of the composite ${ }^{[11]}$. Increased compressive strength is inversely proportional to the percentage of the composite matrix on the board, this is due to better mechanical properties than the matrix filler, it is also due to voids generated is directly proportional to the percentage of the board matrix composites ${ }^{[10]}$. 
The composition of $99 \%$ polyester and $1 \%$ of the variation catalyst $\mathrm{NaOH}$ treatment banana fiber obtained greatest compressive strength value obtained in $\mathrm{NaOH}$ $5 \%$ variation in the randomized position of $81.724 \mathrm{~N} /$ $\mathrm{mm}^{2}$. Judging from the treatment variations $\mathrm{NaOH} 5 \%$, the highest value is obtained because when fibers treated with $\mathrm{NaOH} 5 \%$ strength of the fiber is optimal, wherein the fiber has a small diameter and the pores are narrow so it does not easily absorb water, it is this which makes composites stronger than other $\mathrm{NaOH}$ treatment ${ }^{[3]}$. Jam, when the direction of each fiber spread, its power will be spread in all directions, the composite strength will increase ${ }^{[11]}$.

\subsection{Tensile Strength Testing}

Tensile strength of the composite is strongly influenced by its matrix and filler. Namely binder or matrix composite protectors while yaiu filler filler composite (fiber). Here is a powerful data tensile polyester composite with a variation of the position and $\mathrm{NaOH}$ treatment variations on banana fiber are shown in Table 2.

Table 1. Results of testing the tensile strength of the composite polyester.

\begin{tabular}{ccc}
\hline NaOH (\%) & Number of Fibers & $\begin{array}{c}\text { Tensile Strength } \\
\text { M.Pa }\end{array}$ \\
\hline 0 & 10 & 21.519 \\
3 & 10 & 18.359 \\
5 & 10 & 31.033 \\
7 & 10 & 21.064 \\
\hline
\end{tabular}

For a variety of randomized position obtained graph of tensile strength and $\mathrm{NaOH}$ involves the variation shown in Figure 2.

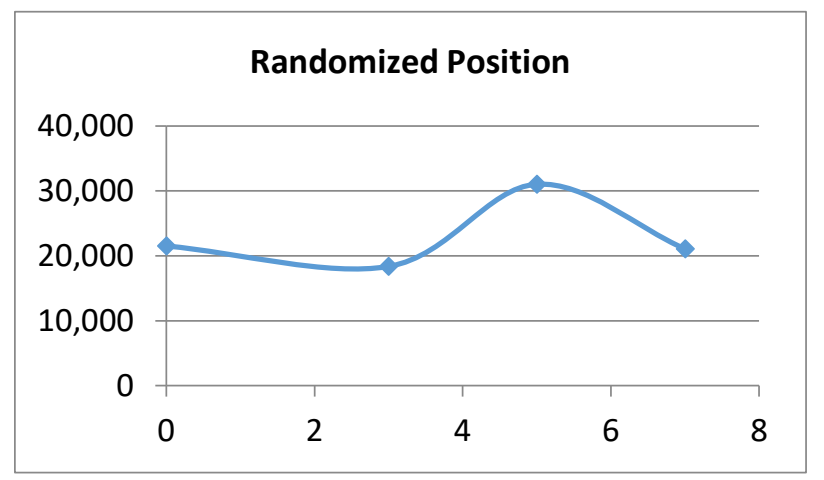

Fig. 2. Graph tensile strength of polyester composite with $\mathrm{NaOH}$ treatment variations.

Based on Figure 2 tensile strength values obtained for randomized positions sequentially, each for $21.519 \mathrm{M} . \mathrm{Pa}$, M.Pa 18.359, 31.033 and 21.064 M.Pa M.Pa, it appears that the greatest tensile strength values for the position held by the variation randomized treatment of $\mathrm{NaOH} 5 \%$ amounting to $31.033 \mathrm{M} . \mathrm{Pa}$. Tensile strength of the composite material is strongly influenced by the composition of the constituent materials, the bond between peguat and filler composite.

Tensile strength composite material obtained from eight specimens with a variation of the position of the fiber that is randomized and $\mathrm{NaOH}$ treatment variations respectively $0 \%, 3 \%, 5 \%$ and $7 \%$. Tensile strength of the composite material in the randomized position with variation of $\mathrm{NaOH} 3 \%$ and $7 \%$ decline in value. At variations $\mathrm{NaOH} 3 \%$ on the position of the randomized of this decline is affected by the onset of voids in the composite, voids or air bubbles affect the bond between the matrix and fiber, the gap in the fiber or fiber form which is less than perfect is causing the matrix will not be able to fill the empty space in the mold, thereby reducing the kekuatankomposit. As for the variation of $\mathrm{NaOH} 7 \%$ in the second position of the decline is not only influenced by the emergence of $a$ void, but also due to the variation of $7 \% \mathrm{NaOH}$ treatment causes the fiber diameter will be enlarged so that the composite strength will be reduced.

The composition of $99 \%$ polyester and $1 \%$ of the variation catalyst $\mathrm{NaOH}$ treatment banana fiber tensile strength values obtained the largest obtained in $\mathrm{NaOH} 5 \%$ variation in the randomized position of 31.033 M.Pa. Judging from the treatment variations $\mathrm{NaOH} 5 \%$, the highest value is obtained because when fibers treated with $\mathrm{NaOH} 5 \%$ strength of the fiber is optimal, wherein the fiber has a small diameter and the pores are narrow so it does not easily absorb water, it is this which makes composites stronger than other $\mathrm{NaOH}$ treatment [3]. Meanwhile, if viewed from a position that is used is an randomized position, the value of higher strength than weaving position, this is because in the randomized position of the mechanical properties of fiber in 1 direction will be weakened, if the direction of each fiber spread, its power will be spread in all directions, the composite strength will increase ${ }^{[11]}$.

\section{Conclusion}

The comparison between the best concentration of $\mathrm{NaOH}$ concentration on composite from banana stem is 5\% at $31.033 \mathrm{M} . \mathrm{Pa}$, while for the best press test is $5 \% \mathrm{NaOH}$ that is equal to $81.724 \mathrm{~N} / \mathrm{mm}^{2}$.

Factors affecting the value of compressive strength and tensile strength value on the composite are the compositions of the constituents, namely the bond between the composite strength and filler, and the presence of voids (air bubbles) in the composite.

Thanks to Kemenristekdikti by means of SIMLITABMAS for supporting grants at Penelitian Dosen Pemula..

\section{References}

1. Nurudin, A., Karakterisasi Kekuatan Mekanik Komposit Berpenguat Serat Kulit Waru (Hibiscus Tiliaceus) Kontinyu Laminat Dengan Perlakuan Alkali Bermatriks Polyester.(2011)

2. Surdia,T., Saito, S., , Pengetahuan Bahan Teknik, PT. Dainippon Gitakarya Printing, Indonesia (1985) 
3. Pramono, Catur, 2005, Pengaruh Perlakuan Alkali Kadar 5\% dengan Lama Perendaman 0 jam, 2 jam, 4 jam, dan 6 jam terhadap Sifat Tarik Serat Pelepah Pisang Kepok (2005)

4. Mueller, D. H., Krobjilowski, A. New Discovery in The Properties of Composites Reinforced With Natural Fiber, Journal of Industrial Textiles, Vol. 33, No. 2-October 2003, pp.111-130 (2003)

5. Riedel, U., Natural fibre reinforced biopolymers as construction materials - new discoveries, 2nd Int Wood and Natural Fibre Composites Symposium, Kassel, Germany (1999)

6. Jamasri, Prospek Pengembangan Komposit Serat Alam Di Indonesia, Pengukuhan Guru Besar Fakultas Teknik Universitas Gajah Mada, pp. 3-19 (2008)

7. Jacobs J.A., Kilduft T.K., Engineering Material Technology Structure, Processing, Property and Selection 2th, Prentice Hall, Inc. A Simon Schuster Company, USA. (1994)

8. Lokantara, P., Analisis Kekuatan Impact Komposit Polyester-Serat Tapis Kelapa Dengan Variasi Panjang Dan Fraksi Volume Serat Yang Diberi Perlakuan $\mathrm{NaOH}$, Fakultas Teknik, Universitas Udayana, Indonesia (2012)

9. Mubarak, A., Karakterisasi Sifat Mekanis Material Biokomposit Unidirectional Laminae Serat Heliconia-Resin Poliester, Jurusan Fisika, IPB (2006)

10. Ach. Kusairi, S., Ni'mah, L., Utilization Fibers and Palm Kernel Shells and Tapioca Adhesive as Matrix in the Manufacture of Composite Boards as an Alternative Raw Material in Furniture Industry, International Journal of ChemTech Research, CODEN (USA): IJCRGG, ISSN: 0974-4290, Vol. 8.,No.4, pp. 1645-1655 (2015)

11. Porwanto, Andri Daniel, Karakterisasi Komposit Berpenguat Serat Bambu dan Serat Gelas Sebagai Alternatif Bahan Baku Industri (2008)

12. Ni'mah, L., Sutomo, E.W., Simbolon, R.J., Manufacture Of Gypsum Board From Eggshell Waste Material, ARPN Journal of Engineering and Applied Sciences, ISSN 1819-6608, VOL. 11, NO. 16, pp. 9933-9940 (2016) 